\title{
TRENDS IN OFFENSIVE TEAM ACTIVITY IN BASKETBALL
}

\author{
Boris Bazanov, Priit Võhandu, Rein Haljand \\ Tallinn University, Tallin, Estonia
}

\begin{abstract}
Boris Bazanov. MA in sport science. Student of Tallin University. The field of scientific research — the creation of computer-based system
\end{abstract} of performance analysis in team sport games and optimization of the training process using the theory of complexity.

\begin{abstract}
The purpose of this paper is to analyze the structure of the models of offense and to determine their efficiency. We were able to determine the teamwork structure by using a system of analysis of the offensive process. The analysis of the team activity as an integrated whole becomes very important.

For this research we observed the Tallinn University basketball team, which plays in Division One of the Estonian league. The data was gathered from 600 ball possessions in 8 recorded games of the regular season. The data we collected was analyzed by the means of data mining. This research has helped to work out the basics of the analytical system of the teamwork aspect. The analyzing system of the competitive activity of the game, enables us to find out interesting offensive models from the data.

The results show that the team scoring (points/possession) as the main indicator of analyzed offenses was equal to 1.13 on average with a frequency of $48 \%$. The 1-2 s duration period of ball possession in offensive zone proves to be most effective (scoring 68\%). The most effective transition period is under $1.82 \mathrm{~s}(62 \%)$. The scoring of set offense is $44 \%$ in the mean. On the basis of this information, the coach can find more convenient time lapses in the game's performance. The analyzing system worked out through that, helps coaches to develop performance and promote learning.
\end{abstract}

Keywords: performance analysis, data mining, efficiency.

\section{INTRODUCTION}

$\mathrm{T}$ The main aim of the offensive teamwork is to score points. During the game there are changes in the structure of the game, which are caused by different reasons. For instance, it may depend on the tempo, the defensive formation of the opposite team or on the variety of used offensive models amongst others. It is necessary to analyze this information in order to arrange the training process more effectively. The purpose of this paper is to analyze the structure of the models of offense and to determine their efficiency. To the present day, scientificmethodical analysis of literature shows that the shooting technique, the physical preparation and the physiological aspects of the players have been studied the most (Hudson, 1985; Mcinnes et al., 1995; Miller, Bartlett, 1996; Rojas et al., 2000). Some studies have concentrated their attention on the efficiency indicators of the game. L. Mendes and M. Janeira (2001) have found that the main impact factor that defines winning and losing teams is defensive rebounding. J. Sampaio and 
M. Janeira (2003) have found in their research, that in close games (those with final score differences between 1 and 8 points), game type influences the result (regular season or play-off) and game location (home or away). Globally, regular season profile was best discriminated by successful free-throws, whereas play-offs profile was best discriminated by offensive rebounding.

Team ball possession is considered one of the central indicators. Both offense and defense activity efficiency is determined by dividing the points earned by ball possession (points/possession) in the game. This kind of a method helps to compare the team's activity efficiency in different games (Trezeguet, 2003).

It is common knowledge that basketball is a complicated team sport game. Because of that incorporation of the separate technical and tactical elements into the integral whole is one of the most important tasks in the analysis and synthesis of the coaching process. The main idea of our research is based on the principal that the integrative usage of the technical and tactical preparation of the basketball players in it's whole meaning opens new perspectives in the quality development of the game of basketball.

\section{METHOD}

The analyzing system of the given research requires the use of video-recorded games and a computer form of notational analysis. The Tallinn University basketball team was under observation during their participation in Division One of the Estonian Championship. Data was gathered from six hundred $(n=600)$ possessions in eight $(n=8)$ recorded games. Further processing of the recorded game was done using the DartTrainer Basic version 2.5.3 programme (Dartfish, 2001).

During the observation of the recorded games the following data was fixed:

- the type of offense: fast break, early offense or set offense;

- the beginning: after steal, defensive rebound or inbound;

- the time in possession during the transition, ball possession in the offensive zone and total time;

- the count of elements in the offensive zone during one team's ball possession: dribbles, passes, screens on the ball, screen off s the ball, shots;

- the outcome actions.
The time of ball possession starts from the moment when the player catches the ball and ends when the ball either leaves the hands of the shooter or when the opposition takes possession of the ball. Time is stopped in rebound and out of bounds situations. The time of transition and the time of ball possession in the offensive zone were fixed separately. The time duration was measured to an accuracy of $0,02 \mathrm{sec}$. When fixing the number of elements, depending on the need, one segment of ball possession was observed many times using slow motion or observation frame by frame.

The gathered data was analyzed by the means of WizWhy programme (data mining). Programme summarises the data and presents the main patterns. It meets this target by listing the relations between all the values in each field and the dependent variable. The method employs a unique algorithm that segments numeric fields in an optimal way and displays the relation between each interval and the value under analysis. WizWhy lists the rules that relate between the dependent variable and the other fields. This analysis of the basic rules and trends results in the summary of the data. The rules are formulated as "if-then" sentences (WizSoft, 2002). National Basketball Association (NBA) coaching staffs started to use PC-based data mining application to discover interesting patterns in basketball data in the 19951996 season (Bhandari et al., 1997).

The trend report presents the one-condition relations in the data, and as such it summarises the data. If-then rules represent sufficient conditions (the "if" condition is a sufficient condition for the result). Minimum confidence of the if-then rules is equal to 0.66 and if-then not rules is equal to 0.72 . Maximum number of conditions in a rule: 3 .

\section{RESULTS}

The results of summary report showed that the team scoring (points/possession) as the main indicator of analyzed offenses was equal to 1.13 on average with $48 \%$ frequency. The scoring of analyzed set offenses was equal to 1.06 on average with $44 \%$ frequency.

Selection of if-then rules (association rules) for the team scoring (dependent variable) more than the average 1.13 (predicted value) is shown in Table 1. 
Table 1. If-then rules for the scoring more than $\mathbf{1 . 1 3}$ points per possession

\begin{tabular}{|c|c|c|c|c|c|c|}
\hline \multirow{3}{*}{$\begin{array}{c}\text { Rule } \\
\mathrm{Nr}\end{array}$} & \multirow{2}{*}{\multicolumn{3}{|c|}{$\begin{array}{c}\text { If } \\
\text { Conditions }\end{array}$}} & Then & \multirow{3}{*}{$\begin{array}{c}\text { Confidence } \\
\text { level }\end{array}$} & \multirow{3}{*}{$\begin{array}{c}\text { Significance } \\
\text { level }\end{array}$} \\
\hline & & & & Offense & & \\
\hline & 1 & 2 & 3 & & & \\
\hline 1 & Fast break & 1 dribble in off zone & Sum of elements 3 & Successful & 0.72 & $<0.001$ \\
\hline 2 & Fast break & $\begin{array}{c}\text { Total time } 2.00- \\
8.00 \mathrm{sec} \\
\end{array}$ & $\mathrm{x}$ & Successful & 0.82 & $<0.001$ \\
\hline 3 & Fast break & 1 dribble in off zone & $\mathrm{x}$ & Successful & 0.8 & $<0.000001$ \\
\hline 4 & Fast break & $\begin{array}{c}\text { Time in offensive } \\
\text { zone } 1.00-2.00 \mathrm{sec}\end{array}$ & $\mathrm{x}$ & Successful & 0.74 & $<0.01$ \\
\hline 5 & Fast break & $\begin{array}{l}\text { Teamwork intensity } \\
\text { index is } 1.19-1.82\end{array}$ & $\mathrm{x}$ & Successful & 0.81 & $<0.01$ \\
\hline 6 & Beginning: steal & Fast break & $\mathrm{x}$ & Successful & 0.72 & $<0.01$ \\
\hline 7 & Beginning: steal & $\begin{array}{l}1 \text { pass in offensive } \\
\text { zone }\end{array}$ & $\mathrm{x}$ & Successful & 0.8 & $<0.001$ \\
\hline 8 & $\begin{array}{c}\text { Time in offensive zone } \\
1.00-2.00 \mathrm{sec}\end{array}$ & $\begin{array}{c}1 \text { dribble in } \\
\text { offensive zone }\end{array}$ & $\begin{array}{c}\text { Didn’t lose } \\
\text { offensive rebound }\end{array}$ & Successful & 0.94 & error $=0$ \\
\hline 9 & $\begin{array}{c}\text { Time of transition is } \\
1.00-2.00 \mathrm{sec}\end{array}$ & $\begin{array}{c}\text { Didn't lose offensive } \\
\text { rebound }\end{array}$ & $\mathrm{x}$ & Successful & 0.9 & $<0.0000001$ \\
\hline 10 & $\begin{array}{c}\text { Time in offensive zone } \\
1.00-2.00 \mathrm{sec}\end{array}$ & Lay up & $\begin{array}{c}\text { Didn't lose } \\
\text { offensive rebound }\end{array}$ & Successful & 0.96 & $<0.0000001$ \\
\hline 11 & $\begin{array}{c}\text { Time in offensive zone } \\
1 ., 00-2.00 \mathrm{sec}\end{array}$ & Sum of elements 2 & $\begin{array}{c}\text { Didn't lose } \\
\text { offensive rebound }\end{array}$ & Successful & 0.92 & $<0.00001$ \\
\hline 12 & $\begin{array}{c}\text { Time in offensive zone } \\
1.00-2.00 \mathrm{sec} \\
\end{array}$ & $\mathrm{x}$ & $\mathrm{x}$ & Successful & 0.66 & $<0.01$ \\
\hline 13 & $\begin{array}{l}\text { Time of transition is } \\
5.00 \mathrm{sec}\end{array}$ & $\begin{array}{l}\text { Time in offensive } \\
\text { zone } 2.00- \\
10.00 \mathrm{sec}\end{array}$ & Without turnover & Successful & 0.7 & $<0.001$ \\
\hline 14 & $\begin{array}{c}\text { Time of transition is } \\
5.00 \mathrm{sec}\end{array}$ & Scr off`s 3-4 & Without turnover & Successful & 0.72 & $<0,1$ \\
\hline 15 & $\begin{array}{c}\text { Time of transition is } \\
5.00 \mathrm{sec}\end{array}$ & Long range shot & $\begin{array}{c}\text { Didn't lose } \\
\text { offensive rebound }\end{array}$ & Successful & 0.92 & error $=0$ \\
\hline 16 & Total time is $12.00 \mathrm{sec}$ & No miss shot & $\mathrm{x}$ & Successful & 0.76 & $<0.01$ \\
\hline 17 & $\begin{array}{c}\text { Time in offensive zone } \\
3.00-10.00 \mathrm{sec} \\
\text { (aver. } 7.44 \text { ) }\end{array}$ & Passes 2 & Without turnover & Successful & 0.64 & $<0.01$ \\
\hline 18 & 2 passes & Long range shot & $\mathrm{x}$ & Successful & 0.71 & $<0.01$ \\
\hline 19 & 5 passes & No scr off`s & Long range shot & Unsuccessful & 0.8 & $<0.01$ \\
\hline 20 & $\begin{array}{l}\text { Beginning: inbound in } \\
\text { defensive zone }\end{array}$ & $1-2$ screen on & Without lay-up & Unsuccessful & 0.7 & $<0.01$ \\
\hline 21 & Set offense & $1-2$ screen on & With lay-up & Successful & 0.78 & $<0.01$ \\
\hline 22 & 1 screen off & $\mathrm{x}$ & $\mathrm{x}$ & Successful & 0.72 & $<0.01$ \\
\hline 23 & $\begin{array}{c}\text { Time in offensive zone } \\
12.00-33.00 \mathrm{sec} \\
\text { (aver 16.38) }\end{array}$ & With lay up & $\mathrm{x}$ & Successful & 0.69 & $<0.01$ \\
\hline 24 & $\begin{array}{c}\text { Time in offensive zone } \\
11.00 \mathrm{sec} \\
\end{array}$ & $\mathrm{x}$ & $\mathrm{x}$ & Unsuccessful & 0.73 & $<0.1$ \\
\hline 25 & $\begin{array}{c}\text { Time of transition is } \\
3.00 \mathrm{sec}\end{array}$ & Without screen off & $\begin{array}{c}\text { Total time } \\
14.00-33.00 \mathrm{sec} \\
\text { (aver 18.87) }\end{array}$ & Unsuccessful & 0.74 & $<0.001$ \\
\hline
\end{tabular}

Note. Minimum confidence of if-then rules (successful) $=0.66$; if-then not rules (unsuccessful) $=0.72$.

\section{DISCUSSION}

Our analyzing system gives an opportunity to determine the efficiency of the models of offense. The trend report showed that the fast break was the most effective (66\%) game type. The efficiency of the early offense was equal to the team average. The team used the type of set offense in $77 \%$ of all ball possessions with efficiency equal to $44 \%$ (see Figure 1). This results are in accord with earlier research made by Tavares and Gomes (2003) where they found that the main game method used by high level junior teams was the set offense with a frequency equal to $74.6 \%$. Our analysis of the one-condition relations between type of beginning and scoring showed that the efficiency of offense was higher when it starts after steal (59\%) or defensive rebound (51\%). In situations (302 cases) where the team began their offensive activity with inbound in the defensive 
zone the efficiency (43\%) was more-or-less equal to the mean scoring of set offense. Such information gives us the opportunity to rate the team performance separately by offensive types.

The analysis of the time in possession showed that the ball possessions (79) with a total time duration of up to $6.04 \mathrm{sec}$ had the $68 \%$ efficiency. The most offenses in this time period belong to fast breaks (Tavares, Gomes, 2003). The scoring drops when time in possession increases (Figure 2).

In figure 3 we can see the analyzed team's onecondition relation between scoring and time of ball possession in the offensive zone. The trend report showed that the most effective (68\%) duration period of ball possession in the offensive zone was between $1-2$ sec. Mainly this period responds to fast break situations. The sufficient conditions for the result are shown in Table 1 (rules $\mathrm{nr} 4$, 8, $10,12)$. It was followed by the $3-10 \mathrm{sec}$ period with 52\% efficiency (317 cases). 11-16 sec (165 cases) was the lowest scoring period (36\%). The

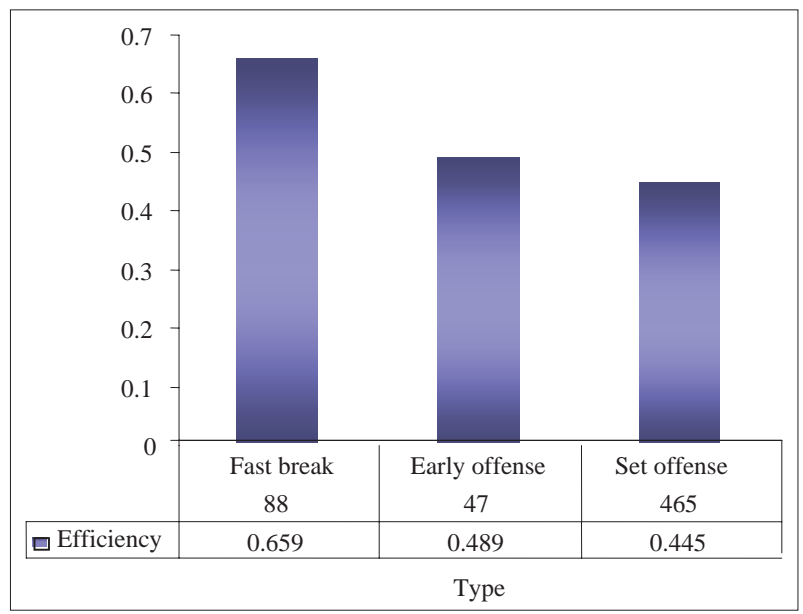

Figure 1. The relationship between type of offense and scoring

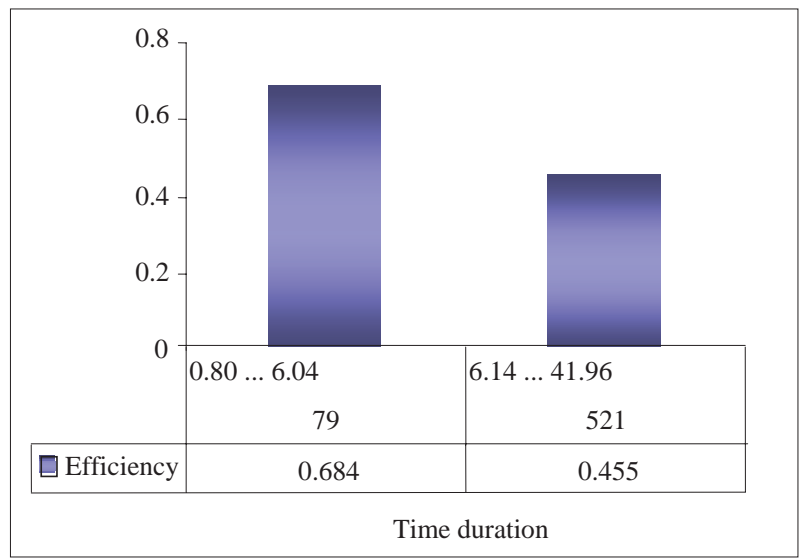

Figure 2. The relationship between total time in possession and scoring final duration period of ball possession is between 17 -36 sec (65 cases). It can happen in situations where players of the opposite team commit a personal foul which is followed by an inbound or the team wins the offensive rebound The scoring in this period was equal to the team's average. This kind of information tells us that the team has to improve the uninterrupted offensive activity with time duration in the offensive zone longer than $11 \mathrm{sec}$ and increase the use of fast breaks and set offenses with a time duration in the offensive zone between 8-10 sec.

Analysis of the transition period showed that team scoring was higher (62\%) in situations with a time duration under $1.82 \mathrm{sec}$ or between $5-8 \mathrm{sec}$ (52\%). The first time period belongs to fast break situations. The second is followed by set offense. On the received information we can presume that there are two effective models of offense - fast break with a time duration of transition under 2 seconds which is followed by time in possession

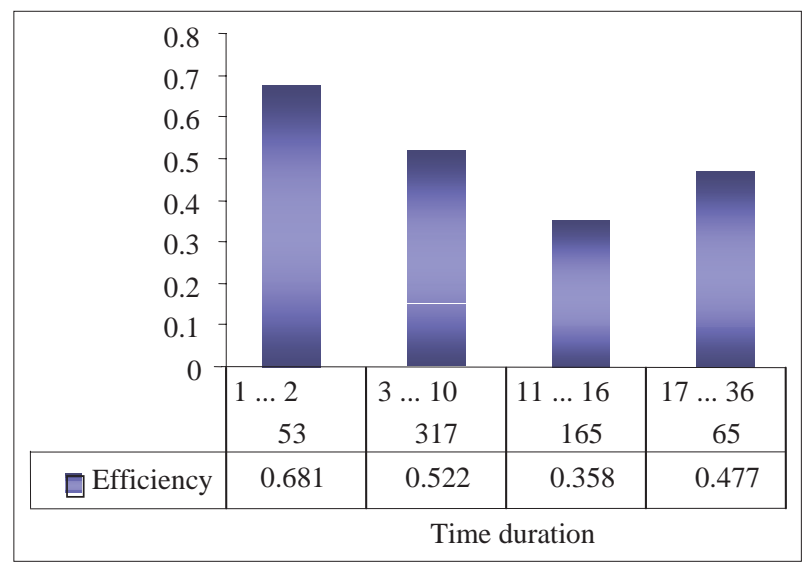

Figure 3. The relationship between time in possession in the offensive zone and scoring

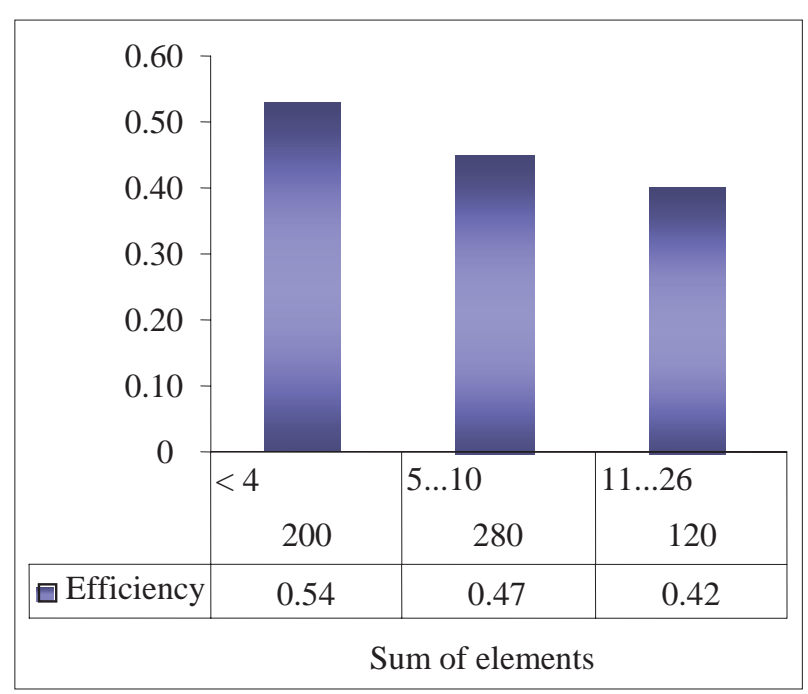

Figure 4 . The relationship between sum of elements in the offensive zone and scoring 


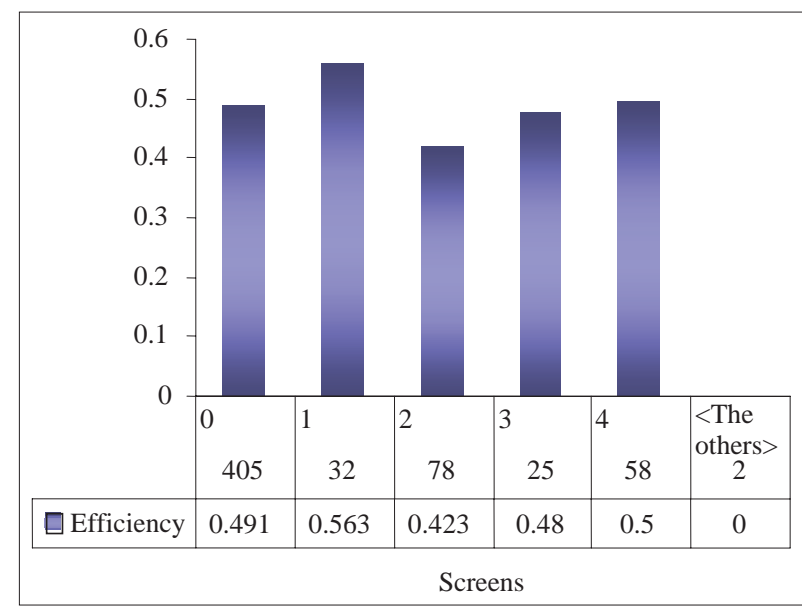

Figure 5. Screen off's the ball

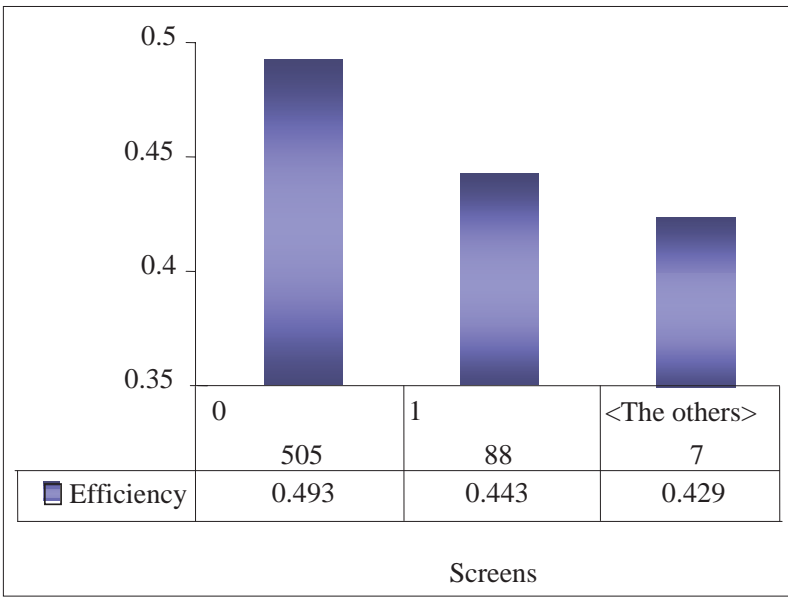

Figure 6. Screens on the ball

in the offensive zone between $1-2$ sec and set offense with time of transition equal to $5 \mathrm{sec}$ and time in possession in the offensive zone between 8-10 sec (see Table 1 ).

Figure 4 illustrates the one-condition relations between the sum total of all the elements the team uses in the offensive zone during one possession and the result. We can see that, when increasing the number of elements, the efficiency of the offensive teamwork drops. Scoring was higher when the team used under 4 elements. In game situations this means making a fast break in the offensive zone with the minimal number of elements with high intensity. Two elements are usually equal to pass or dribble and lay-up; three-dribble, pass, lay-up (see Table 1, rules 1, 3, 5, 7, 11). Adding a fourth element in game situations brings the team to early offense, often ending with a jump shot. The next two groups belong to the set offense. In the first, depending on the game situation, the team should perform 5-10 elements. For example $9-10$ elements holds the dribbles of $1-2$ pla-

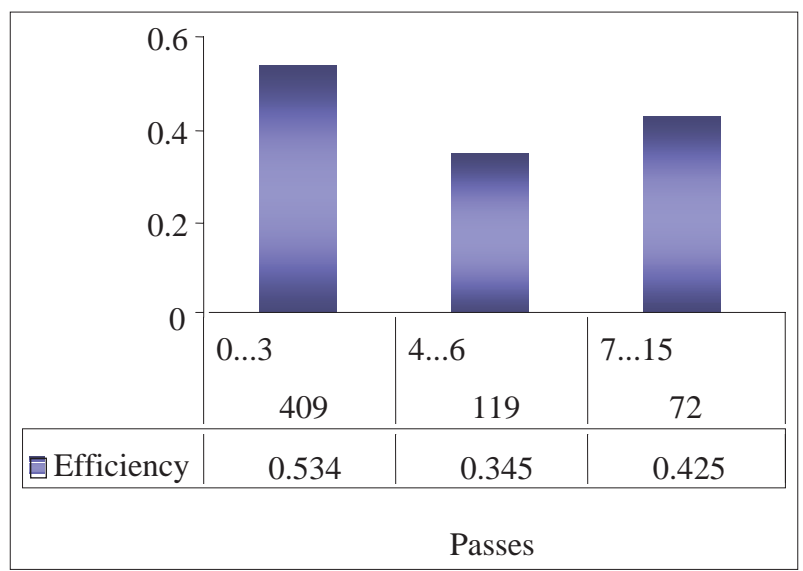

Figure 7. Passes in the offensive zone

yers, $2-3$ passes, $3-4$ screen off's the ball and a shot. If the combination is done skillfully the time duration of ball possession in the offensive zone is between $8-10 \mathrm{sec}$. The efficiency of this group was equal to $47 \%$ and exceeded the average level of set offense (44\%).

In the second group, the team had used 11 or more elements. In the main the time duration of this group is more than $11 \mathrm{sec}$. The efficiency of this group (42\%) drops under the team average level of set offense. Regulated time ( $24 \mathrm{sec})$ that limits offense activity, starts to have it's effect at the ending of the offense. Examples of activities that are not conducive to good results include: using too many elements and performing a shot in unfavorable conditions etc.

The count of screens (both on and off the ball) indicate the combination the team has used. With regards to this point the combination with 2 screen off's the ball scored less (78 cases with $42 \%$ efficiency). The scoring was higher when the team used 1 (32 cases with 56\% efficiency) or 4 (58 cases with $50 \%$ efficiency) screen-off's the ball (see Figure 5; Table 1, rules 14, 22). In situations where the team used screens on the ball the scoring was lower (see Figure 6). This information points out the advantages and disadvantages in the team performance. In this case, the players of the team under analysis have to collaborate using $1,3-4$ screen off's the ball. The team should improve the activity in situations where players are using screens on the ball and combinations with 2 screen off's the ball. One possibility to improve the team activity with screens on the ball is to use lay-ups at the end of the offense (see Table 1, rule 21).

The analyzed team's relationship between scoring and a number of passes during ball possession in the offensive zone can be seen in Figure 7. 
There were 409 offenses when players used under three passes. The scoring (53\%) of those offenses was above the average (48\%). The scoring drops (34\%) when players passes the ball between 4 and 6 times (119 cases).

According to the research information we can pressume that efficiency of the team activity increases by means of fast breaks and skillfully done set offenses. The results of our earlier research (Bazanov et al., 2005) show that both of them have to be done with high teamwork intensity. These results are in accord with research made by E. Tsamourtzis et al. (2005) where they found that the winners indicated more fast breaks, with more successful two point shots and more fast break situations 1 on 0 . They concluded that the fast break constitutes an important factor for the attainment of the victory.

\section{CONCLUSIONS}

The aim of this study was to analyze the structure of the models of offense and to determine their efficiency. According to the research a number of conclusions can be made. The team scoring (points / possession) as the indicator of analyzed offenses was equal to 1.13 on average with $48 \%$ frequency. The average scoring of set offense was equal to 1.06 with $44 \%$ frequency. The offenses with the total time duration of up to $6.04 \mathrm{sec}$ had $68 \%$ efficiency. On the received information we can presume that there are two effective models of offense - fast break with a time duration of transition under 2 seconds which is followed by time in possession in the offensive zone between $1-2$ seconds with the minimal number ( 3 ) of elements in the offensive zone including lay-up and set offense with time of transition equal to $5 \mathrm{sec}$ and time in possession in the offensive zone between $8-10$ sec. The main discovered weaknesses of the team under analysis which have to be improved are uninterrupted offensive activity with time duration in the offensive zone longer than 11 sec and situations with screens on the ball. One opportunity to improve both of them is to use lay-ups at the ending of the offense.

On the basis of such information the coach can evaluate the activity of the team, find more convenient time lapses in the game performance and correct the strategy for future games. The analyzing system worked out through that helps coaches to develop performance and promote learning.

\section{REFERENCES}

Bazanov, B., Võhandu, P., Haljand, R. (2005). Offensive teamwork intensity as a factor influencing the result in basketball. International Journal of Performance Analysis in Sport, Vol. 5, 2, 9-16.

Bhandari, I. et al. (1997). Advanced Scout: Data Mining and Knowledge Discovery in NBA Data. Data Mining and Knowledge Discovery, Vol. 1, 1, 121-125 (5).

Dartfish. (2001). DartTrainer software. Available from World Wide Web. Internet link: <http://www.dartfish. com.

Hudson, J. (1985). Prediction of basketball skill using biomechanical variables. Research Quartely for Exercise and Sport, 56, 115-121.

Mcinnes, S., Carlson. J., Jones, C. and McKenna, M. (1995). The physiological load imposed on basketball players during competition. Journal of Sports Sciences, 13, 387-397.

Mendes, L., Janeira, M. (2001). Basketball performance - multivariate study in Portuguese professional male basketball teams. In M. D. Hughes and F. Tavares (Eds.), Notational Analysis of Sport - 4. pp. 103-111. Cardiff: UWIC.
Miller, S., Bartlett R. (1996). The relationship between basketball shooting kinematics, distance and playing position. Journal of Sports Sciences, 14, 245-253.

Rojas, F. J., Cepero, M., Ona, A., Gutierrez, M. (2000). Kinematic adjustments in the basketball jump shot against an opponent. Ergonomics, Vol. 43, 10, 1651-1660.

Sampaio, J., Janeira, M (2003). Statistical analyses of basketball team performance: understanding teams' wins and losses according to a different index of ball possessions. International Journal of Performance Analysis in Sport, Vol. 3, 1, 40-49.

Tavares, F., Gomes, N. (2003). The offensive process in basketball - a study in high performance junior teams. International Journal of Performance Analysis in Sport, Vol. 3, 1, 34-39.

Trezeguet, J. (2003). Measuring Players at "Formulas". Internet link: <http://eba-stats.com/articles/articles>.

Tsamourtzis, E., Karypidis, A., Athanasiou, N. (2005). Analysis of fast breaks in basketball. International Journal of Performance Analysis in Sport, Vol. 5, 2, 17-22.

WizSoft. (2002). Data and Text Mining. Introduction. Internet link: http://www.wiz'Asoft.com/ 


\title{
PUOLIMO TENDENCIJOS ŽAIDŽIANT KOMANDINI KREPŠINI
}

\author{
Boris Bazanov, Priit Võhandu, Rein Haljand \\ Talino universitetas, Talinas, Estija
}

\begin{abstract}
SANTRAUKA
Tyrimo tikslas - išanalizuoti puolimo modeliu struktūrą ir nustatyti ju efektyvumą. Komandinès veiklos, kaip integruotos visumos, analizė yra labai svarbi. Tyrimo metu stebėta Talino universiteto krepšinio komanda, žaidžianti Estijos lygos pirmame divizione. Buvo stebimos vaizdu užfiksuotos 8 reguliaraus sezono rungtynès. Duomenys gauti analizuojant 600 kamuolio valdymo atveju.

Tyrimas padėjo nustatyti komandinio žaidimo analizės sistemos pagrindus, leido atrasti įdomius puolimo modelius. Rezultatai rodo, kad komandinis kamuolio pataikymas (taškai / kamuolio valdymas), kaip pagrindinis analizuojamas puolimo rodiklis, buvo vidutiniškai lygus 1,13, esant $48 \%$ metimų dažnumui. 1-2 sekundžių trukmès kamuolio valdymas puolimo zonoje buvo efektyviausias (pataikymas 68\%). Efektyviausias perejjimo laikas — 1,82 sekundès (62\%). Pataikymas serijinio puolimo metu vidutiniškai buvo lygus $44 \%$. Remdamasis šia informacija, žaidimo metu treneris gali efektyviau išnaudoti varžybų laiką. Ši sistema padeda treneriams gerinti žaidimą ir skatina juos mokytis.
\end{abstract}

Raktažodžiai: veiksmo atlikimo analizè, duomenų gavimas, efektyvumas.

Gauta 2006 m. sausio 22 d.

Received on January 22, 2006

Priimta 2006 m. gegužès 25 d.

Accepted on May 25, 2006

Boris Bazanov

Talino universitetas

(Tallinn University)

Regati Avenue 1, 11911 Tallinn

Estija (Estonia)

Tel +3725579974

E-mail boris.baz@mail.ee 